\title{
Community Adoption of Watershed Management Practices at Kindo Didaye District, Southern Ethiopia
}

\author{
Merkineh Mesene Mena*, Aklilu Bajigo Madalcho, Efrem Gulfo and Gashaw Gismu \\ Wolaita Sodo University, Department of Natural Resource Management, Ethiopia
}

Submission: August 04, 2018; Published: September 05, 2018

*Corresponding author: Merkineh Mesene Mena, Wolaita Sodo University, Department of Natural Resource Management, P0 Box-138; W/Sodo, Ethiopia, Email: bajigoaklilu05@gmail.com

\begin{abstract}
Watershed degradation resulted in long-term reduction in the quantity and quality of land resources, which has negative impact on the livelihoods of the rural poor who rely on land resources. The overall intention of this work was assessing Community Adoption of Watershed Management practices at Kindo Didaye district, by taking 6\%(40HHs) randomly selected households from the watershed. Through semi structured questionnaire, focus group discussion, transect walk, key informant interview with guide checklist, primary data was collected. By using percentage, frequencies, and chi-square (X2 test) data was analyzed. The findings revealed that almost all respondents (100\%) have recognized the watershed degradation problem; and the role of watershed management practices as a response. The key finding of the research presents that due to different interventions the livelihood of the community was diversified and enhanced especially; income, crop productivity, forest cover, water and food availability. The chi-square test result showed that the factors such as age, education, family size, and transport/ market and extension service were positively and significantly correlated. It is concluded that the watershed management practice is adopted by the community as it plays a significant role to enhance household's livelihood, ecosystem balance and cope with climate change impacts.
\end{abstract}

Keywords: Environmental Role; Natural Resource Management; Socio-Economic; Watershed Management

\section{Background}

Natural resources in Ethiopia are under extreme stress. Land degradation, including deforestation, soil erosion and biological soil degradation are rampant throughout the country. Because of its topographic nature, removal of the living land cover brings about soil degradation [1-3]. Agriculture is the main sector of the Ethiopian economy and contributes approximately $42 \%$ to the GDP and employs over $80 \%$ of the population [4,5]. Despite its role, agricultural production is constrained by high climate variability where rainfall distribution is extremely uneven both spatially and temporally, and this has negative implications for the livelihoods of people [6]. Ethiopia is one of the most vulnerable country to the adverse effects of climate change due to its geographical location, topography and heavily dependent on rain-fed agriculture, under-development of water resources, high population growth rate, low economic development level, inadequate road infrastructure in drought prone areas, weak institutions in combination with low adaptive capacity $[7,8]$. Consequently, millions of Ethiopians often face severe food scarcity [9]. Land degradation in the form of soil erosion has been considered as among the major factors responsible for the recurrent malnutrition and famine problems in Ethiopia [10]. It is estimated that more than $50 \%$ of the land in Ethiopia is affected by soil erosion, $25 \%$ being seriously eroded and $4 \%$ of it has no longer productive [11]. Watershed degradation in Ethiopia is one of the main constraints for agricultural productivity, resulting from the interaction of natural and anthropogenic factors, including erratic rainfall, rugged topography and unsustainable land management practices, both in areas of food crops and in grazing lands. Watershed degradation not only decreased land productivity but also increased social problems [12,13].

As in URL (http://www.colorado.edu/; Kumar, 2009): Integrated watershed management approach is the process of formulating and implementing a course of action involving natural and human resources in a watershed, taking into account the social, political, economic, and institutional factors operating within the watershed and the surrounding river basins and other relevant regions to achieve specific social objectives and is generally recognized as the most practical and efficient way to improve water quality and other environmental indicators while maintaining regional economic viability. The impacts of major watershed development programmes have been outlined in terms of biophysical impacts, environmental impacts, socioeconomic impacts and overall economic impacts. According to the participatory watershed management guidelines, the objective of watershed management is to improve the livelihoods of rural communities and households through

(i) SWC for productive uses; 
(ii) Rainwater harvesting for improved groundwater recharge;

(iii) Promoting sustainable farming systems and agricultural productivity adopting suitable soil, water, nutrient and crop management practices;

(iv) Rehabilitating and reclaiming marginal lands through appropriate conservation measures, such as planting of trees, shrubs and grasses depending on existing potential; and

(v) Enhancing the income of smallholders by diversifying agricultural practices and income-generating activities (IGAs).

In general, watershed management creates opportunities for reclaiming degraded land, improving soil fertility, water resources development, increasing agricultural production, off-farm activities, diversifying income sources and providing access to markets, where the benefits are realized at household and community level. In Ethiopia, watershed management programs have commenced in a formal way at about 1970s. From that time up to the late 1990s, implementation was typically a government-led, top-down, incentive based (food- for-work) approach that prioritized engineering measures. During this phase, the programs focused primarily on reducing soil erosion. In the early 2000s, community-based integrated watershed development was introduced to promote watershed management as a means to achieve broader integrated natural resource management and livelihood improvement objectives within prevailing agro-ecological and socio-economic environments [14]. The application of community-based watershed management (CBWM) is the most modern and recently developed method of land rehabilitation and climate change adaptation. Similarly, watershed management in Wolaita zone has grown in recent years from more technical interventions to restore degraded lands. The study sub-watershed was severely degraded and prone to frequent rain failure and unsuitable for crop cultivation. As a result the residents were vulnerable to climatic and market shocks. Despite of this, Community Based Watershed management (CBWM) is a widely implemented in the woreda. Yet, these management activities have not been documented. Moreover, impacts of these activities on climate change adaptation are also not evaluated. Hence, this study was conducted to assess Community Adoption of Watershed Management practices at Kindo Didaye district, Wolaita, Ethiopia (Figure 1).

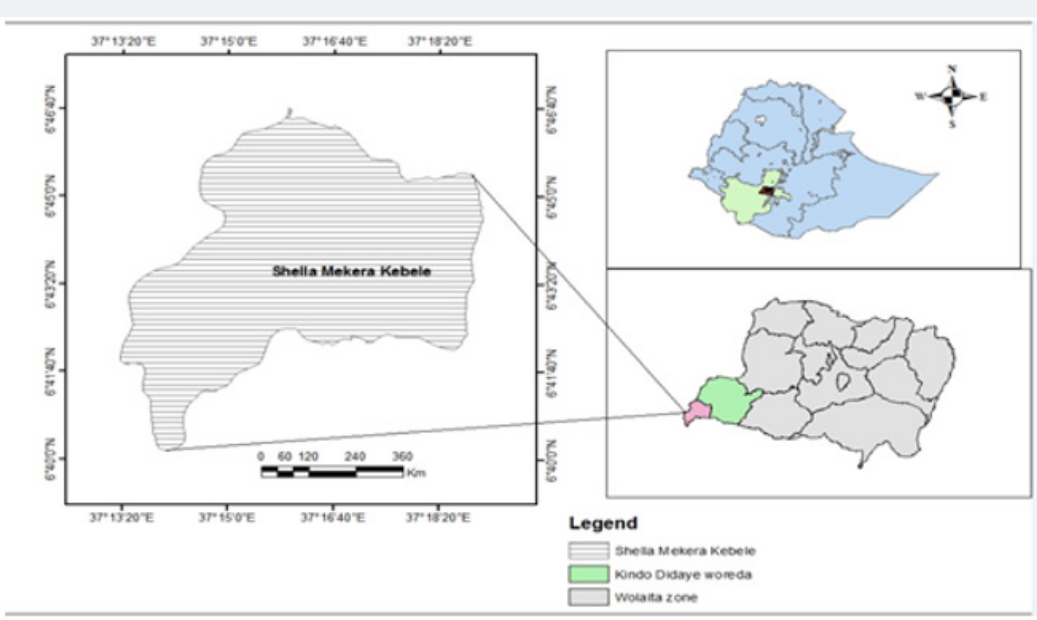

Figure 1: Map of study site (Shella Mekera kebele).

\section{Methodology}

\section{Data Collection and Analysis}

Prior to the research work, an over view of the research areas was carried out, questionnaire was prepared, pre-tested and modified accordingly. A combination of methods such as face-to-face interview through semi-structured questionnaire and focus group discussion was used to collect relevant data primary data. In order to ensure the reliability and validity of the data collected; triangulation with key informants' interview, and direct observation was made. Secondary sources of information were also collected from district level reports and plans in concerned offices. The study site was selected together with supervisors, district leaders and experts including DAs; purposively based on the historical severity of soil erosion and intensive conservation intervention practices implemented in the area in the last four years. Proportional to the population of villages for in-depth household interview with semi-structured questionnaire, simple random sampling technique was used. Random sampling with the reason that the community is homogeneous with regards to the livelihood, topography, engagements in watershed management activities, small sized land holding, and their attitude on watershed management activities. Total household size of Shella Meqera district is 664 and $6 \%$ of it ( 40 households) were considered to be sufficient and representative to achieve the objectives of the study. The head of the household is considered to be the unit of analysis because she/he has been the ultimate decision-maker with respect to farming and conservation activities. 
Then, the collected data was organized, analyzed and interpreted by the use of various types of methods and systems. After feeding the data in to SPSS Ver. 16.0, statistical analysis was carried out. Descriptive statistics (i.e. frequency, percentage, figure, table, chart, and graphs), and Cross tabulation Chi-square test were conducted. MS-Excel was used to generate tables and graphs.

\section{Result and Discussion}

\section{Back Ground Distribution}

Age and Sex Status of the Study Area: The age composition of a family is worth mentioning as it is a characteristic that has implication on the availability of labor for the various activities undertaken by the family. From the total household heads interviewed for this study, $12.5 \%$ were 18 -28 years old, $47.5 \%$ between 29 and $39,32.5 \%$ between 40 and 50 and the remaining $7.5 \%$ were above 51 years old (Table 1 ). The chi-square test result showed that there was statistically significance mean difference on age at $\mathrm{P}<0.05$ levels. As it can be observed, majority of the respondents $(47.5 \%)$ in the study area are under the age class of 29 and 39 years old. This indicates that, the population structure in the sturdy area is dominated by productive age class, and there is high chance of the tedious and labor demanding watershed management practices.

Table 1: Age and sex composition of the site.

\begin{tabular}{|c|c|c|}
\hline Age Category & Frequency & Percent \\
\hline $18-28$ & 5 & 12.5 \\
\hline $29-39$ & 19 & 47.5 \\
\hline $40-50$ & 13 & 32.5 \\
\hline $51-60$ & 3 & 7.5 \\
\hline Total & 40 & 100.0 \\
\hline Sex Category & Frequency & Percent \\
\hline M & 25 & 62.5 \\
\hline F & 15 & 37.5 \\
\hline Total & 40 & 100.0 \\
\hline
\end{tabular}

The distributions of sampled household heads by sex constitute $62.5 \%$ and $37.5 \%$ for male and female, respectively (Table 1). These household heads include a wide range of people: village elders, decision makers (local administration), younger people, older people, poor and rich farmers. The chi-square test result showed that there was no statistically significance mean difference on family size at $\mathrm{P}<0.05$ levels. However, the community is dominated by male headed households. Although women participation is equally important in the watershed management activities, the responsibility of carrying out this heavy watershed management activity is by male.

Educational Status: Educational background of sampled household heads is believed to be an important feature that determines the readiness of the household head to accept new ideas and innovations. As educational status of the household head increases, it is assumed to increase the transfer of relevant technology and as a result increase farmers' knowledge about the cause, severity and consequence of land degradation. The empirical result shows that the educational status of farmers in the study area is considerably low. In the area as a whole, significant share (about 45\%) of the household heads were illiterate (Figure 2). Eleni (2008) in Tulla district, Adugna (2008) in Assosa and Fikru (2009) in Koga watershed also said the largest proportion is illiterate (no formal education). From the remaining $55 \%$, about $42.5 \%$ of them have attended elementary education, $10 \%$ have attended secondary school and $2.5 \%$ have attended above secondary education. The chi-square test result showed that there was statistically significance mean difference at $\mathrm{P}<0.05$ on the education.

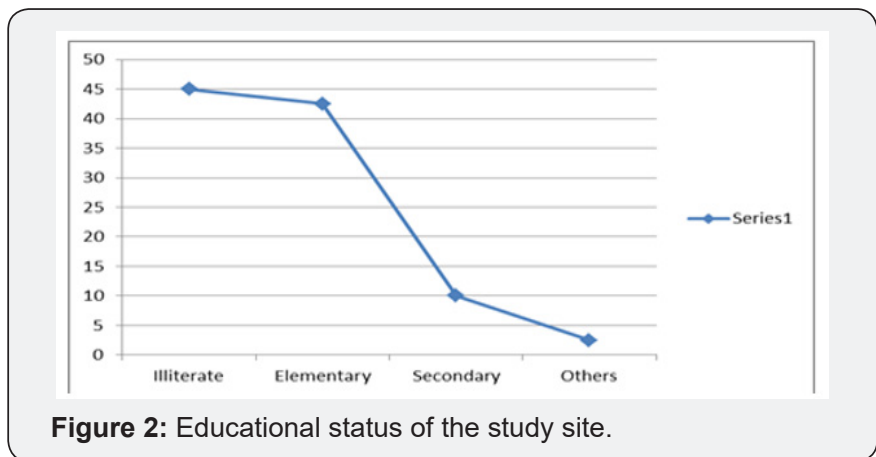

Family Size: Household size and characteristics are directly related to the supply and demand conditions for basic human needs such as food, shelter, health and educational facilities which in turn directly or indirectly influence the decision for watershed activities for a farming system [14]. Family size and composition affect the amount of labor available for farm, offfarm and household activities and also determines the demand for food. About $55 \%$ of the household heads in the current study sites consists of 4-7 numbers of family members (Figure 3 ). The chi-square test result showed that there was statistically significant mean difference on family size at $\mathrm{P}<0.05$ levels. This result was disagrees with the works of Amsalu (2006) in Beressa watershed and Fikru (2009) in Koga watershed that found insignificant difference in terms of family size of the sampled households.

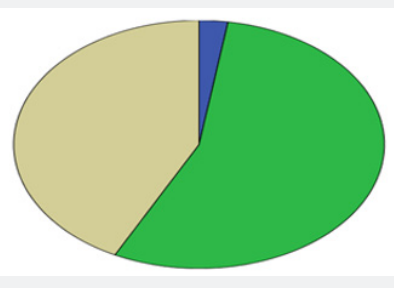

Figure 3: Composition of family size.

Landholding: Small farm size limits the decision of farmers to implement conservation structures i.e. structures hold large space and it becomes difficult for the farmer to plow oxen and carry out activities. In the study area, all of the interviewed farmers owned land. As in most of the highlands of the country; the landholding of farmers in the study area is very small. From 
the total respondents, the largest proportion (90\%) has less than 0.5 ha of land holding while the remaining $5 \%$ has a land size of 0.5-1.0 ha (Table 2). The per capita landholding of the country is expected to decline from average of 1.76 ha in 1985 to 1.1 and 0.66 ha in years 2000 and 2015 respectively [15].

Table 2: Distribution of sample HHs by farm size.

\begin{tabular}{|l|l|l|}
\hline Landholding in ha & Frequency & Percent \\
\hline$<0.5$ & 36 & 90.0 \\
\hline $0.5-1.0$ & 4 & 10.0 \\
\hline Total & 40 & 100.0 \\
\hline
\end{tabular}

Community Understanding on Causes and
Consequences of Soil Erosion

With regard to causes of soil erosion, some farmers have a clear idea of why they have been facing erosion problems; whereas others only have general ideas rather than detailed causes of erosion. Based on the independent factor analysis, of the total respondents $97.5 \%$ was identified cultivation on steep slope as aggravates soil erosion. Since the topography in the study area is ragged and almost all parts have $>30 \%$ slope, being the most aggravating factor, while the land scarcity (Table 3) and large family size (Figure 2) is enforces the local people to cultivate steep slopes; so during heavy rain coupled with poor management at household level aggravated the soil erosion. On the other hand, about $87.5 \%$ of respondents agree as over cultivation of land for long time without amendment on the functioning capacity of soil can induce soil erosion. As it is known that continues cultivation of the land leads to disturbance on the soil aggregates, and loss of organic matter, the soil rain water retention capacity declines, and run off occurs. About 70\% respondents were agreeing also on the poor agricultural practices management as it leads to soil erosion. Of them, $65 \%$ were identified excessive and showery rainfall was considered as one of the erosion hastening factor in combination with the other factors with high values above. On the other hand, overgrazing (60\%), and deforestation (35\%) were described as causes of soil erosion in the site (Figure 4). The latter two variables ware list perceived by the community my due to the fact that, the community has very low extent of communal lands possession with forests and rangelands for grazing except some area closures. Hence, these factors got less value for being taken as major soil erosion resulting factors. However, most of the respondents considered that combination of two or more factors were being used as the causes of soil erosion. The chi-square test result showed that there was a statistically significant mean difference on the major soil erosion causing factors in Figure 4. The finding of Adugna (2008) in Assosa also indicated that these variables were statistically significantly different. Apart from this, others as major causes of soil erosion do not bring any statistically significant effect. Farmers in the study district have perceived differently regarding to the effects of soil erosion problems. The community perceives that multiple effects were demonstrated from single erosion hazard incidences in a given area. Accordingly, productivity/yield decline (100\%), plot size reduction $(85 \%)$, difficulty on land preparation $(80 \%)$, and decline in soil depth so as to the change in type of crop grown $(47.5 \%)$ respectively were commonly understood effects in the district (Figure 5). Most of the respondents considered combination of two or more effects at a time of soil erosion rather than single negative outcome.

Table 3: Problems encountered with conservation practices in watershed.

\begin{tabular}{|c|c|}
\hline Common Challenges & \% \\
\hline High labor requirements & 80 \\
\hline Reduce farm size & 60 \\
\hline $\begin{array}{c}\text { Technical difficulty to } \\
\text { implement }\end{array}$ & 62.5 \\
\hline difficult to turn oxen & 40 \\
\hline Sources of rodents & 35 \\
\hline Not effective & 20 \\
\hline
\end{tabular}

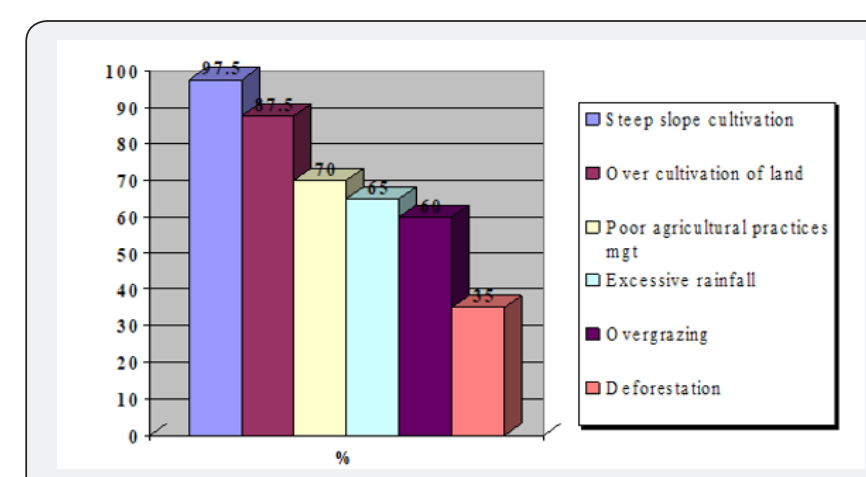

Figure 4: Major causes of soil erosion.

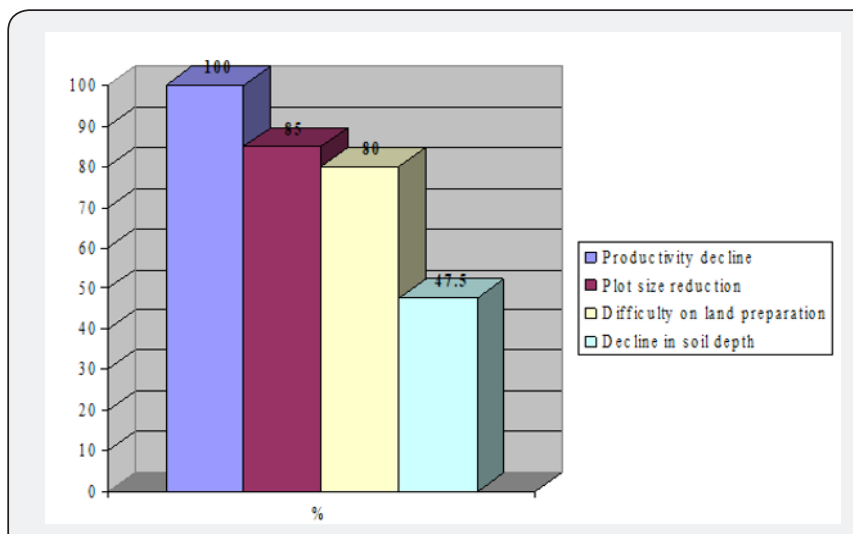

Figure 5: Major effects of soil erosion.

\section{Community Experience on Noticing Soil Erosion Problems}

With respect to perceiving soil erosion problems and its related hazards in time frame, farmers vary considerably. Majority (45\%) of the respondents were experienced this problem for the last 15 years, some $(40 \%)$ were noticed it since 10 years, and the remaining $15 \%$ were perceived it since 5 years (Figure 6). This indicates that, majority of the community 
understand as the soil erosion and the subsequent challenges on the agricultural land productivity is deep rooted problem in the area. Perceiving soil erosion as a serous hazard to sustainable agricultural production is the most important determinant of adoption of conservation measures [16,17]. On the other hand, when farmers do not acknowledge soil erosion as a problem, they will not expect benefits from controlling erosion and it is highly likely that they will decide against adopting any conservation technologies [18].

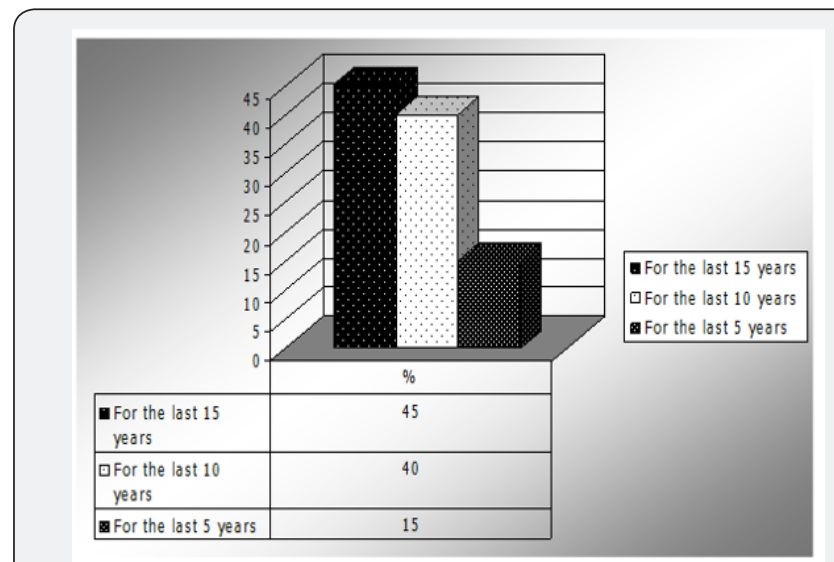

Figure 6: Local community experience on soil erosion problems.

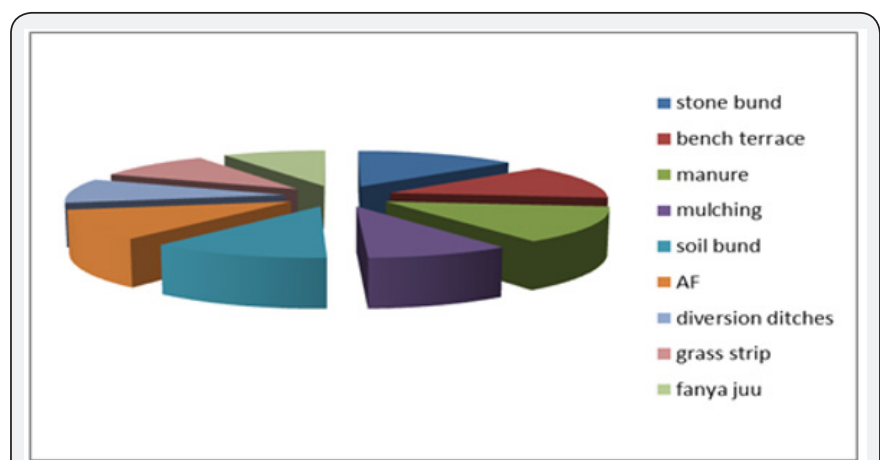

Figure 7: Basic watershed management practices.

Land degradation through soil erosion is the principal cause of short-falling of agricultural productivity and total production (crop, livestock). Soil erosion results in the productivity loss of soil on-site by decreasing soil depth and off-site at lower catchment through sedimentation of unfertile sub-soil on the surface soil. Farmers suggest that the decline in the productivity of their farm plots were due to increase in soil erosion following heavy rainfall that washes out the top fertile soil. Surprisingly all of the respondents $(100 \%)$ in the site perceived the problem and its severity (Figure 6) The finding corresponds to the findings of other studies made in other part of the country such as (Aragaw, 2005; Merkineh, 2016; Belay, 1992; Amsalu, 2006; Moges and Holden, 2006 and Wodeamlak, 2003) that the community is getting aware of soil erosion problems. 3.3. Watershed management practices in the district Watershed based soil and water conservation activities are becoming popular practices with Wolaita farmers. In doing it, both biological and physical conservation measures, albeit with different emphasis [19] is applied. To combat soil degradation, especially soil erosion in the site, farmers use a number of traditional and improved SWC technologies now a time after long year's vulnerability to erosion hazards, and land productivity loss. Hence, one or more of them such as manure application (87.5\%), mulching (60\%), soil bund (75\%), agroforestry (72.5\%), diversion ditches (60\%), grass strip (65\%), fanya juu (57.5\%), bench terrace $(85 \%)$, and stone bund (90\%) were practiced (Figure 7). At household level, multiple approaches were most likely implemented, but integration of biological with mechanical soil and water conservation techniques amalgamation.

The findings from various methods i.e. survey, participant observation, discussion with key informants and various groups; on the issue of whether soil erosion is controllable or not indicated that, it could if measures taken on time. With this regard, the new areas were also entered to watershed management program, and it becomes part of political commitment at local level, and the community obligation to insure survival. Annually there is watershed management campaign for 30 successive days to work together for free of cash payment. About $80 \%$ of the farmers had willingness to try new soil and water conservation technology whenever introduced to the area. This indicates that the community is well aware of the soil erosion problem, and the need of watershed management practices as the only option for livelihood security and environmental stability. The response is in agreement with the findings of various works in different sites [20].

\section{Environment and Socio-Economics in Watershed Management}

Watershed management contributes to all sectors (agriculture such as crop production and livestock, water availability and quality, health, ecosystem service, socio economic and all human livelihood activities) directly or indirectly through chain reaction available between sectors. The potential impact of watershed management indicates its contribution to cope with climate change risks and hazards [21].

Discussion with FGD and KI indicated that surface and groundwater availability increased due to the various water storage structures including biological and physical soil and water conservation resulted in increased cropping intensity, and helped households to find new ways to raise incomes while reducing environmental risks. These improvements were consistent with the work of [22] examined that the role of watershed management for climate change adaptation through income, soil fertility, land productivity, forest, water and food supply improvement. The watershed management practices helped households to diversify their livelihood activity and it's in agreement with the finding of Hadush [23]. Income or livelihood diversity is important to cope up with climatic change risks. If one income source were lost, then still have other sources of income which make households and communities resilient during hazards [24]. 
In the study area and surrounding catchments, the ownership of livestock is considered as an indicator for wealth and food security; as livestock is an integral part of the farming systems and they are particularly important for increasing the resilience of vulnerable poor people subjected to climatic and income shocks. The major Livestock's in the study area includes livestock, equine, small ruminants and poultry. Watershed management has an impact on livestock size and type. As from discussions, there were deceasing trend in livestock size and type due area closure on communal lands. Almost all households have not self-own grazing land in the study area. However, the overall performance of individual animals in household has been increased since the availability of feed resources increased for cut-and-curry feeding as a response to watershed management as mentioned by group discussion. This makes the community to positively look towards the implementation of watershed management activities although there are hindering factors.

\section{Soil Fertility Maintenance, and Agricultural Extension}

In addition to various watershed management practices, inorganic fertilizer application in the area is common with varying rates. In the past years, the land was exposed for degradation that obliged the farmers to adapt inorganic fertilizer. About $95 \%$ of the respondents were fully or partly applied inorganic fertilizer (DAP \& UREA) to their cultivated land while $5 \%$ of the respondents were not apply due to increase in the price of inorganic fertilizer. Whereas, the other organic form of soil fertility maintenance was not common except some agroforestry practices in combination with cassava alley cropping in the study district.

On the verge of integrated watershed management practice in the area, extension service is very important to disseminate technology through continuous skill gap filling in the community. The information obtained and the knowledge and skills gained through extension message and contents accelerates farmer's decision on conservation practices. BoARD is the responsible organization to give agricultural extension services to the farmers in the rural area. The organization has a structure that extend down to Peasant Association (PA) level. From the result of survey, about $97.5 \%$ of the respondents have reported that they have access to extension services. When considering weekly time of visit, $50 \%$ responded as they see three to five times, $45 \%$ get one or two times, and around 5\% get the extension workers more than five times a week. The chi-square test result showed that there was a statistically significant mean difference on extension services.

On the other hands, credit is used to improve the ability of households at critical times of the year to buy agricultural inputs. About $60 \%$ of respondents reported that they had received agricultural credit in the past years and they also mentioned the sources where they access i.e. government $(72.5 \%)$, NGOs (22.5\%), and others (5\%). This credit has big role in facilitating integrated watershed managing investments, including soil and water conservation measure implementation.

\section{Challenges of Watershed Management Practices}

However, the farmers considered the soil erosion problems in the last year, and shifting to implement watershed management in integrated approach, some challenges were affecting their decision on conservation intervention practices. Farmers gave range of reasons, most of which are applicable to the whole farm and some are more relevant at the plot level. Most of the respondents mentioned a combination of problems. On the occasion of multiple answers were possible, farmers identified six major problems such as high labor requirements (80\%), reduce farm size $(60 \%)$, difficult to implement technically (62.5\%), difficult to turn oxen (40\%), sources of rodents (35\%), and not effective (20\%) (Table 3). Labor requirement was the biggest challenge so as to the child and young migration to urban area is very high in the district due to resource limitation, and land degradation. Hence, the old aged small family members remain with the responsibility of this heavy duty. Introduced SWC measures characterized by high labor inputs and high portion of occupied arable land. The result of this study is in line with the finding of [25-36]. On the other hand, the access to markets can play a major role in determining patterns of land use and land management. Where markets are well-developed and competitive, farmers can be expected to respond largely to the profitability of alternative land uses and management options, and the outcomes are likely to be relatively efficient. As a means of transport to the market, farmers in the study area $20 \%$ was used animals to transport their goods to market, $62.5 \%$ use laborers, and $17.5 \%$ of the farmers use the car (Figure $8)$. The better transport system is lacking in the area that affect the value chain of the products in the watershed. It has negative implication on the adoption of watershed management. The result of chi-square analysis showed that there was statistically significant mean difference at $\mathrm{P}<0.05$ on the means of transport to the nearby markets.

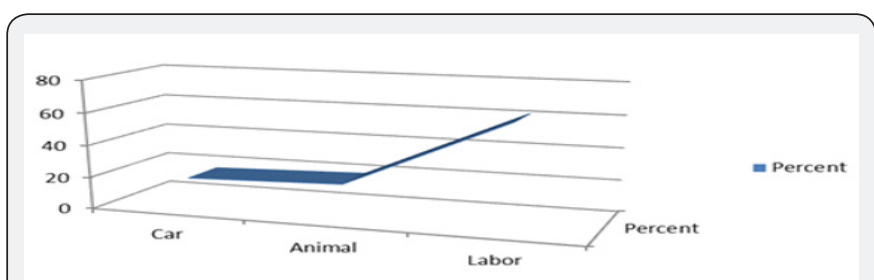

Figure 8: Means of transport of products in the study area.

\section{Conclusion and Recommendation}

An integrated approach to watershed management would ideally address the complex system dynamics in watersheds, and achieve global environmental benefits, and locally maintain holistic social, economic and ecological balance. After understanding about the impacts of land degradation in the area, the local communities made paradigm shift on their attitude towards watershed management and show high adoption 
status. Currently the community performs many activities in the study area to support their livelihood and to cope up with the environmental change as various conservation intervention practices such as soil bund, deep trench, terraces, hill side terrace, check dams, and water diversions, fanya juu, manure application, and agroforestry to less extent. The different interventions were enabled to improve crop productivity, food availability, water status, livelihood diversification, income, rehabilitation from the degraded lands and reduction in migration and climatic hazards. In turn to improve household's resilience to climate change in the study area. However, in the implementation of such activities some challenges were facing such as shortage of land and natural rainfall variability. Some of the respondents show as they are not voluntary to plant tree on their farmlands, and to implement mechanical soil and water conservation since they give priority for food crop production on their small sized farmland. In addition, lack of skill to implement standard based SWC techniques, low rate of adoption of agricultural technologies and inputs, and lack of integration between sectors are indicated. Based on the result and discussion, the following points are forwarded as a future line of work:

a) Linking physical and biological conservation activities with income-generating and livelihood improvement activities is very important to insure the watershed management activities as a tool for sustainable livelihood.

b) Attention should be given to female and marginal farmers to increase their level of awareness for adoption watershed management practices adoption.

c) Continuous impact assessment, monitoring and follow up of conservation intervention is necessary.

\section{References}

1. Girma Kelboro (2000) A Participatory Approach to Agroforestry in Watershed Management, MSc thesis, case study at Yannasie, SNNPR, Ethiopia, Wagenin, the Netherlands.

2. Bishaw B (2001) Deforestation and land degradation on the Ethiopian Highlands: A strategy for physical recovery. Paper presented at the International Conference on Contemporary Development Issues in Ethiopia, Kalamazoo, Michigan, USA.

3. Forch G (2009) IWM A successful tool for adaptation to climate change. Siegen, Germany.

4. Diao X (2010) Economic importance of agriculture for sustainable development and poverty reduction: The case study of Ethiopia. Paper presented at the OECD Global Forum on Agriculture: Policies for Agricultural Development, Poverty Reduction and Food Security, November 29-30, 2010, Organization for Economic Cooperation and Development (OECD) Headquarters, Paris, France.

5. ATA (Ethiopian Agricultural Transformation Agency) (2013) Annual report 2013/2014: Transforming agriculture in Ethiopia. Addis Ababa, Ethiopia: Ethiopian Agricultural Transformation Agency (ATA).

6. Georgis K, Dejene A, Malo M (2010) Agricultural based livelihood systems in drylands in the context of climate change: Inventory of adaptation practices and technologies of Ethiopia. Environment and Natural Resources Management Working Paper 38. Rome, Italy: Food and Agriculture Organization of the United Nations (FAO).
7. NAPA (National Adaptation Plan for Action) (2007) Climate Change NAPA of Ethiopia. Addis Ababa: MoWER and NMA, Ethiopia.

8. Arnold (2003) Adaptation to climate change in the developing world. Progress in Development Studies 33: 179-195.

9. Kaur (2013) Ethiopian Green Economy Addis Ababa, Ethiopia.

10. Amede TL, German C, Opondo S, Rao, A Stroud (2006) Integrated Natural Resource Management in Practice: Enabling Communities to Improve Mountain Livelihoods and Landscapes. Proceedings of a conference held on October 12-15, 2004 at ICRAF Headquarters, Nairobi, Kenya. Kampala, Uganda: African Highlands Initiative.

11. Taha N (2002) Challenges and Strategies towards Sustainable Land Use in North Wollo Zone of the Amhara National Regional State. $12^{\text {th }}$ ISCO Conference, Beijing.

12. Sertse Sebuh (2007) Study and design guidelines on watershed management with reference to forestry. Bureau of Agriculture and Rural Development (BoARD), Mekelle Tigray.

13. Darghouth S, Ward C, Gambarelli G, Styger E, Roux J (2008) Watershed Management Approaches, Policies and Operations: Lessons for Scaling Up. Water Sector Board Discussion Paper Series Paper No 11. The World Bank, Washington, DC.

14. Fikru A (2009) Assessment of Adoption Behavior of SWC Practices in the Koga Watershed, Highlands of Ethiopia.

15. Kassaye B (2004) Land use and Land Cover Change in the Central Highlands of Ethiopia: The Case of Yerer Mountain and its Surroundings. MA Thesis, AA University, Ethiopia.

16. Tesfaye B (2003) Understanding Farmers: Explaining soil and water conservation in Konso, Wolaita and Wello, Ethiopia. PhD Dissertation Wegeningen University, The Netherlands.

17. Amsalu A (2006) Caring for the Land: Best practices in SWC in Beressa watershed, highlands of Ethiopia. PhD Thesis Wageningen UR- with ref - with Summary in English and Dutch.

18. Woldeamlak B, Sterk G (2002) Farmers participation in soil and water conservation activities in the Chemoga watershed, Blue Nile Basin, Ethiopia. Land Degradation and Development 13: 189-200.

19. MoARD (Ministry of Agriculture and Rural Development) (2001) Soil and Water Conservation Manual, Guide Line for Ethiopia.

20. Assefa A (2011) Community Based Watershed Development for Climate Change Adaptation in Choke Mountain: The Case of Upper Muga Watershed in East Gojjam of Ethiopia.

21. Hadush M (2015) The Role of Community Based Watershed Management for Climate Change Adaptation 1(1): 11-35.

22. Adger WN (1998) Observing Institutional Adaptation to Global Environmental Change: Theory and Case Study from Vietnam. Working Paper GEC 98-21. Centre for Socialand Economic Research on the Global Environment, University of East Anglia, Norwich, and University College London.

23. Adugna T (2008) Farmers Perception on Soil Erosion and Decision on Land Management in Assosa Woreda, Ethiopia. MSc thesis, Hawassa Univerisity, Ethiopia.

24. Anonymous (2009) Climate Change- A Burning issue for Ethiopia. Green forum Conference Proceedings No. 2.

25. Aragaw M (2005) Forest conversion soil degradation farmers perception nexus: Implications for sustainable land use in the southwest of Ethiopia. Ecology and Development Series.

26. Belay T (1992) Farmers' perception of erosion hazards and attitude towards soil conservation in Gununo, Wolayita. Ethiopia Journal of Development Research 14(2): 32. 
27. Eleni T (2008) Continued Use of SWC Practices: A Case study in Tulla District, Ethiopia. Msc thesis, Wageningen University, The Netherlands p. 57.

28. Fikru A (2009) Assessment of Adoption Behavior of SWC Practices in the Koga Watershed, Highlands of Ethiopia.

29. Gebremedhin B, Swinton SM (2003) Investment in soil conservation in northern Ethiopia: the role of land tenure security and public programs. Agricultural Economics 29: 69-84.

30. Kumar S (2009) Impacts of Watershed Development Programmes: Experiences and Evidences from Tamil Nadu, India.

31. Ludi E (2004) Economic Analysis of Soil Conservation: Case Studies from the Highlandsof Amhara region, Ethiopia. Centere for Development and Environment Institute of Geography, University of Berne, Switzerland pp. 416.
32. Merkineh Mesene (2016) Determinants of choice decision for adoption towards Conservation Intervention Practices, Southern Ethiopia. Global journal of Env'tal Science 16(6): 33-41.

33. Moges A, Holden M (2006) Farmers perceptions of soil erosion and soil fertility loss in southern Ethiopia Land Degradation and Development 18: 543-554.

34. Semgalawe ZM, Folmer H (2000) Household adoption behaviour of improved soil conservation: the case of the North Pare and West Usambara mountains of Tanzania. Land Use Policy 17: 321-336.

35. Singh B, Squire T, Strauss J (1986) Agricultural household models. Johns Hopkins University Press, Baltimore.

36. Woldeamlak B (2003) Land Degradation and Farmers Acceptance and Adoption of Conservation Technologies in the Digil Watershed, Northwestern.

Your next submission with Juniper Publishers will reach you the below assets

- Quality Editorial service

- Swift Peer Review

- Reprints availability

- E-prints Service

- Manuscript Podcast for convenient understanding

- Global attainment for your research

- Manuscript accessibility in different formats ( Pdf, E-pub, Full Text, Audio)

- Unceasing customer service

Track the below URL for one-step submission https://juniperpublishers.com/online-submission.php 